\title{
Efektivitas Terapi Hinosis Lima Jari Terhadap Ansietas Klien Hipertensi di Puskesmas Rawasari Kota Jambi Tahun 2017
}

\author{
Mohd. Syukri \\ Poltekkes Kemenkes Jambi \\ Email : syukrimohd15@gmail.com
}

\begin{abstract}
Five-finger hypnosis is a movement that tightens and relaxes the muscles in one part of the body at one time which can present a relaxed condition physically and psychologically, by thinking of a pleasant experience (Keliat, 2011). Useful for giving inner peace to individuals. reduce anxiety, worry and anxiety, reduce tension and reduce blood pressure, lower heart rate and sleep soundly. This study aims to determine the effectiveness of five-finger hypnosis therapy against anxiety hypertension clients at Putri Ayu Health Center, Jambi City. Quasi experimental design pre-post test with without control. The sample was 33 people with a total sampling technique. The results showed that there was an effect of five-finger hypnosis therapy on anxiety in hypertensive clients ( $p$ value $<0.05$ ). There was a decrease in anxiety after five finger hypnosis therapy was carried out. Five finger hypnosis therapy is recommended to be applied as nursing therapy in treating hypertensive clients with anxiety.
\end{abstract}

Keyword: Five-finger hypnosis Therapy, anxiety, hypertension clients.

\section{PENDAHULUAN}

Kesehatan jiwa adalah suatu kondisi sehat emosional, psikologis, dan sosial yang terlihat dari hubungan interpersonal yang memuaskan perilaku dan koping individu efektif, konsep diri yang positif dan kestabilan emosional (Johnsons, 1997 dalam Videback, 2008). Kesehatan jiwa juga mempunyai sifat yang harmonis dan memperhatikan semua segi dalam kehidupan manusia dalam berhubungan dengan manusia lainnya yang akan mempengaruhi perkembangan fisik, mental, dan sosial individu secara optimal yang selaras dengan perkembangan masingmasing individu.

Menurut WHO (2009), prevalensi masalah kesehatan jiwa mencapai $13 \%$ dari penyakit secara keseluruhan dan kemungkinan akan berkembang menjadi $25 \%$ di tahun 2030, prevalensi secara global ansietas ada sebanyak $11,6 \%$ dari jumlah seluruh penduduk Indonesia atau sekitar 24.708.000 jiwa. Selain itu prevalensi ansietas di negara berkembang pada usia dewasa sebanyak $50 \%$ baik akut mapun kronis dengan perbandingan wanita dan pria 2:1 dan lebih dari $85 \%$ ansietas diakibatkan penyakit fisik, salah satu diantaranya adalah hipertensi.

Ansietas dapat memicu terjadinya peningkatan adrenalin yang berpengaruh pada aktivitas jantung yaitu terjadinya vasokonstriksi pembuluh darah dan dapat meningkatkan tekanan darah (Endang ,dkk 2014). Salah satu masalah kesehatan yang dapat menyebabkan ansietas adalah penyakit hipertensi dan aspek - aspek psikologis yang menyertainya. (Kemenkes RI, 2013).

Dampak dari ansietas dapat mempengaruhi stimulasi sistem saraf simpatis, yang meningkatkan frekuensi darah, curah jantung dan tahanan vaskular perifer, selain itu memacu jantung berdenyut lebih cepat serta lebih kuat, sehingga tekanan darah akan meningkat. Dan apabila tidak segera diatasi dapat menyebabkan pendarahan (Riyadi \& Purwanto, 2009). Ansietas klien hipertensi semakin meningkat dengan kurangnya pengetahuan tentang perawatan penyakit hipertensi yang dideritanya (Prasetya, 2014). Oleh karena itu, klien hipertensi yang mengalami ansietas memerlukan penanganan yang baik dalam menurunkan ansietasnya.
Penderita hipertensi yang mengalami ansietas akan memperlihatkan gejala somatis (timbul gejala pada tubuh) dan rasa gugup atau ketakutan. Gejala somatis yang dapat muncul pada ansietas seperti: kepala terasa pusing atau ringan, diare, berkeringat, kesulitan bernapas, mual dan muntah, hipertensi, palpitasi atau berdebar-debar, pupil melebar atau midriasis, gelisah, tidak bisa diam, tremor atau gemetaran, pingsan, gangguan buang air kecil.

Ansietas tidak hanya menyebabkan gejala-gejala diatas, namun juga mempengaruhi proses berpikir, persepsi, dan proses belajar. Ansietas juga dapat menyebabkan gangguan orientasi tempat, waktu, orang atau kejadian, sehingga terlihat seperti orang kebingungan (confusion). Gangguan proses belajar yang terjadi meliputi penurunan konsentrasi, dan pengulangan.

Psikoterapi relaksasi yang dapat digunakan pasien hipertensi adalah Progressive Muscle Relaxation (PMR) dan terapi hipnotis lima jari. PMR merupakan gerakan mengencangkan dan melemaskan otot-otot pada bagian tubuh. Sedangkan hipnosis 5 jari merupakan terapi generalis keperawatan di mana klien melakukan hipnotis diri sendiri dengan cara klien memikirkan pengalaman yang menyenangkan dengan media lima jari (Keliat, 2011).

Pada survei pendahuluan, diketahui penderita hipertensi sebagian besar kadang muncul perasaan cemas dan sering memikirkan penyakit hipertensi yang dialaminya. Beberapa diantaranya mengatakan khawatir tentang penyakit hipertensi dan sulit tidur serta muncul perasaan yang tidak menentu. Saat ditanyakan tentang tindakan terapi hipnosis lima jari dalam mengatasi kecemasan klien hipertensi, semua penderita hipertensi tersebut mengatakan belum pernah melakukan terapi hipnosis lima jari dalam menurunkan tekanan darah.

Berdasarkan data dari dinas kesehatan Kota Jambi, Puskesmas Rawasari merawat penderita hipertensi terbanyak dibanding Puskesmas lainnya dengan jumlah klien hipertensi sebanyak 4846 penderita. Dari data tersebut lebih dari $80 \%$ mengalami ansietas mulai dari gejala ringan hingga berat.

Salah satu bentuk psikoterapi yang dapat diterapkan pada klien hipertensi dengan ansietas yaitu 
dengan terapi hipnosis lima jari didasarkan pada teori bahwa tanda dan gejala fisiologis akan berhubungan dengan interaksi antara pikiran, perilaku dan emosi (Pedneault, 2008). Berdasarkan penelitian Sulistyarini (2014) terapi relaksasi efektif dalam meningkatkan kualitas hidup, tekanan darah sistolik dan diastolik penderita hipertensi. Menurut penelitian yang dilakukan oleh Hastuti \& Arumsari (2015) ada pengaruh terapi hipnosis lima jari dalam menurunkan ansietas. Hasil penelitian yang dilakukan Endang, dkk tahun (2014) didapatkan terjadi penurunan tingkat ansietas antara kelompok intervensi dan kelompok kontrol. Penurunan tingkat ansietas pada kelompok intervensi sebesar

Menurut Setiawan (2014), manfaat dari terapi hipnosis lima jari antara lain: memberikan ketenangan batin bagi individu, mengurangi rasa cemas, khawatir dan gelisah, mengurangi ketegangan, mengurangi tekanan darah, detak jantung jadi lebih rendah dan tidur menjadi nyenyak

Tujuan Umum: Penelitian ini bertujuan untuk mendapatkan gambaran tentang pengaruh terapi hipnosis lima jari terhadap kecemasan klien hipertensi di puskesmas Rawasari Kota Jambi.

\section{METODE PENELITIAN}

Penelitian ini adalah penelitian dengan metode kuantitatif menggunakan desain "Quasi experimental pre-post test without control' dengan intervensi terapi hipnosis lima jari yang terdiri dari tiga fase; orientasi, kerja dan terminasi. Teknik pengambilan sampel secara total sampling. Penelitian dilakukan untuk menganalisa perubahan tingkat kecemasan penderita hipertensi. Sampel berjumlah 33 orang. Instrumen yang digunakan untuk mengukur kecemasan pasien adalah Hamilton Rating Scale For Anxiety (HRS-A). Pengolahan data dengan editing, coding, processing dan cleaning. Analisis statistik yang dipergunakan yaitu univariat dan bivariat dengan analisis dependen dan independent sample t-test serta uji anova dan korelasi regresi. Etika penelitian yang digunakan peneliti Maleficience, Justice, Anomymous, Beneficence dan/nformed concent.

\section{HASIL DAN PEMBAHASAN}

Menjelaskan bahwa dari 33 orang responden dalam penelitian ini, usia produktif pada responden adalah 41 tahun dengan umur termuda 33 tahun dan tertua 52 tahun yang paling banyak berjenis kelamin perempuan 25 (75,8\%) yang berpendidikan SMP 20 $(60,6 \%)$, bekerja 20 (60,6\%), kawin $24(72,7 \%)$.

Berdasarkan hasil uji statistik tidak ada hubungan umur dengan ansietas dan ada hubungan antara jenis kelamin dengan ansietas $(p<0,05)$. Ada hubungan antara pekerjaan dengan ansietas responden $(p<0,05)$. Ada hubungan pendidikan SD-SMA dengan ansietas. Ada hubungan antara status perkawinan dengan ansietas responden.

Berdasarkan tabel 1 menjelaskan bahwa dari 33 responden rata-rata perubahan tekanan darah dan ansietas setelah dilakukan terapi hipnosis lima jari lebih tinggi dibandingkan sebelum dilakukan terapi hipnosis lima jari.

\section{Tabel 1. Rerata tekanan darah dan ansietas sesudah dilakukan tindakan terapi hipnosis lima jari klien hipertensi di Puskesmas Rawasari Kota Jambi Tahun 2017}

\begin{tabular}{cccc}
\hline Variabel & Sebelum terapi & Setelah terapi & P value \\
\hline Tekanan darah & 13,79 & 19,88 & 0,00 \\
Ansietas & 14,58 & 17,33 & 0 \\
\hline
\end{tabular}

Berdasarkan hasil uji statistik pada tabel 1 bahwa hasil uji statistik dengan nilai $p<0,05$. Rata-rata tekanan darah setelah dilakukan terapi hipnosis lima jari lebih besar dibandingkan sebelum dilakukan terapi hipnosis lima jari. Sebelumnya responden dengan hipertensi kategori stage 2 lebih banyak yaitu 25 (75,8\%) responden. Setelah dilakukan terapi hipnosis lima jari kategori stage 2 berkurang menjadi 12 (36,4\%) responden. Hal tersebut menunjukkan bahwa terapi hipnosis lima jari efektif dalam menurunkan tekanan darah (derajat hipertensi).

Rata-rata ansietas penderita hipertensi setelah dilakukan terapi hipnosis lima jari lebih besar penurunannya dibandingkan sebelum dilakukan terapi hipnosis lima jari. Sebelumnya penderita hipertensi dengan ansietas berat lebih banyak dialami responden yakni sebesar $60,6 \%$ (dialami oleh 20 responden), setelah diberikan terapi hipnosis lima jari, ansietas berat hanya dialami oleh $4(12,1 \%)$ responden, mayoritas responden hanya mengalami ansietas ringan yakni sebesar $51,6 \%$.

\begin{tabular}{lllll}
\hline Variabel & Mean & SD & Min/Maks & $95 \% \mathrm{Cl}$ \\
\hline Hipertensi & & & & \\
Sebelum & 13,79 & 3,09 & $9-22$ & $12,69-14,88$ \\
Sesudah & 19,88 & 3,01 & $12-24$ & $18,81-20,95$ \\
Ansietas & & & & \\
Sebelum & 14,58 & 1,6 & $11-18$ & $14,00-15,15$ \\
Sesudah & 17,33 & 2,16 & $14-22$ & $16,57-18,10$ \\
\hline
\end{tabular}

\section{Pembahasan}

Hasil penelitian menunjukkan bahwa hasil uji statistik ada perubahan derajat hipertensi dan ansietas. Terjadi penurunan grade hipertensi dan penurunan tingkat ansietas setelah diberikan terapi hipnosis lima jari. Responden dalam penelitian ini memiliki pengalaman yang tidak menyenangkan akibat hipertensi yang dideritanya. Nyeri kepala saat terjaga, terkadang disertai mual dan muntah akibat peningkatan tekanan darah interaknium, Penglihatan kabur karena terjadi kerusakan pada retina sebagai dampak dari hipertensi, Ayunan langkah yang tidak mantap karena terjadi kerusakan susunan saraf pusat, Nokturia (sering berkemih di malam hari) karena adanya peningkatan aliran darah ginjal dan filtrasi glomurelurus, Edema dependen dan pembengkakan akibat peningkatan tekanan kapiler (Ardiansyah, 2012).

Sedangkan tanda gejala ansietas yakni palpitasi, jantung berdebar, atau akselerasi frekuensi jantung, berkeringat, gemetar atau menggigil, perasaan sesak nafas dan tercekik, perasaan tersedak, nyeri atau ketidaknyamanan dada, bergantian kedinginan atau kepanasan. (Stuart,2012).

Hasil penelitian ini sejalan dengan penelitian yang dilakukan Endang,dkk (2014) tentang efektifitas terapi hipnotis lima jari untuk menurunkan tingkat ansietas 
pasien hipertensi yang menunjukkan bahwa kondisi pasien sebelum dilakukan terapi pada kelompok kontrol diketahui ada perbedaan yang bermakna antara kedua kelompok. Penelitian lain juga dilakukan oleh Sulistyarini (2013) dengan judul terapi relaksasi hipnosis lima jari untuk menurunkan tekanan darah dan meningkatkan kualitas hidup penderita hipertensi yang didapatkan hasil pada saat pretest yakni penurunan rerata nilai tekanan darah diastolik sebesar 8,34 dan posttest 77,33.

Menurut Probowo (2014) penatalaksnaan ansietas pada tahap penegahan dan terapi memerlukan suatu metode pendekatan yang bersifat holistik, yaitu mencangkup fisik (somatik), psikologik atau psikiatrik, psikososial dan psikorelegius, Gejala atau keluhan fisik (somatik) sering di jumpai sebagai gejala ikutan atau akibat dari kecemasan yang berkepanjangan. Untuk menghilangkan keluhan-keluhan somatik pada organ tubuh yang bersangkutan, sedangkan menurut Keliat, dkk (2011) menyatakan tindakan keperawatatan yang diberikan pada pasien yang mengalami kecemasan dapat dilakukan dengan cara tehnik relaksasi nafas dalam, distraksi, hipnosis lima jari dan melakukan kegiatan spiritual.

Hipnosis lima jari adalah suatu teknik distraksi pemikiran diri dengan menghipnosis diri sendiri. Hipnosis lima jari mampu menurunkan kecemasan seseorang dengan tujuan Mengurangi stress, mengurangi kecemasan. Hipnotis lima jari dilakukan selama 10 menit (Keliat, 2013). Penelitian lain juga menunjukkan bahwa hipnotis lima jari efektif dalam menurunkan tingkat kecemasan responden. Ciptakan lingkungan yang nyaman, bantu klien untuk mendapatkan posisi istirahat yang nyaman duduk atau berbaring, latih klien untuk menyentuh keempat jadi dengan ibu jari tangan, minta klien untuk tarik nafas dalam sebanyak 2-3 kali, minta klien untuk menutup mata agar rileks, dengan diiringi musik (jika klien mau), pandu klien untuk menghipnosis dirinya sendiri. (Setiawan,2014)

Asumsi yang peneliti dapatkan bahwa terdapat efektifitas terapi hipnosis 5 jari terhadap ansietas dan tekanan darah karena terjadi terjadi relaksasi yang didapatkan ketika dilakukan terapi hipnosis lima jari tersebut. Melalui teknik hipnosis lima jari dapat menurunkan ansietas dan tekanan darah karena didalam terapi tersebut terjadi kenyamanan dan rileks sehingga klien yang awalnya mengalami ansietas akan berkurang.

Ansietas tersebut terjadi akibat tekanan darah tinggi yang meningkat yang membuat klien menjadi cemas. karena ansietas yang sudah menurun, maka hipertensi juga dapat terjadi penurunan. Selain itu setelah dilakukan evaluasi pasca tindakan terapi hipnosis lima jari, klien terlihat lebih rileks dan tidak terlihat tegang. Berdasarkan jurnal dan penelitian yang sudah pernah dilakukan bahwa terdapat perbedaan tingkat kecemasan dan tekanan darah sebelum dan sesudah dilakukan hipnosis lima jari yang menunjukkan bahwa terapi tersebut dapat dilakukan seterusnya pada klien hipertensi untuk menurunkan tingkat kecemasan.

\section{SIMPULAN}

1. Tidak ada hubungan antara umur responden dengan ansietas.

2. Ada hubungan antara jenis kelamin responden dengan ansietas.

3. Ada hubungan pendidikan SD- SMA responden dengan ansietas.

4. Ada hubungan antara pekerjaan dengan ansietas.

5. Ada hubungan antara status perkawinan dengan ansietas.

\section{DAFTAR PUSTAKA}

Ardiansyah, 2012. Buku Ajar Medikal Bedah Untuk Mahasiswa. Jakarta: Diva Press

Endang, dkk. 2014. Efektisssfitas Terapi Hipnotis Lima Jari Untuk Menurunkan Tingkat Ansietas Pasien Hipertensi. Jurnal Keperawatan.Vol 2. No. 3. 2433

Evangelista (2016) Pengaruh Hypnosis 5 Jari Terhadap Tingkat Kecemasan Pasien Sirkumsisi di Tempat Praktik Mandiri Mulyorejo Sukun Malang. Jurnal Keperawatan. Vol 1. No 2.

Fitria, dkk. Laporan Pendahuluan Tentang Masalah Psikososial. Jakarta: Salemba Medika

Hastuti \& Harumsari. 2015. Pengaruh Terapi Hipnotis Lima Jari Untuk Menurunkan Kecemasan Pada Mahasiswa Yang Sedang Menyusun Skripsi Di STIKES Muhammadiyah Klaten. Jurnal IImu Kesehatan Vol. 10 No 21

Hawari, D. 2008. Manajemen Stres, Cemas dan Depresi. Jakarta: FKUI

Hidayat, A. 2007. Metode Penilitian Keperawatan Dan Tehnik Analisis Data. Jakarta: Selemba Medika

Hidayat, A. 2011. Metode Penilitian Keperawatan Dan Tehnik Analisis Data. Jakarta: Selemba Medika

Katz, et al., 2013. Jurnal Online Center For Desease Control And Prevention Life Expectancy. Avaible at. http://www.cdc.gov/inchs/fasttats/lifexpec.htm. Accessed August 6

Keliat. 2013. IImu Keperawatan Jiwa Komunitas. Jakarta: EGC

Keliat. 2016. Prinsip Dan Praktek Keperawatan Kesehatan Jiwa Stuart. Jakarta: Elseiver

Kemenkes RI, (2013).Riset Keperawatan Dasar (2013). https:// www.Riskesdas.com. Diakses paada tanggal 26 Desember 2017

Notoatmodjo, S. 2010. Metodologi Penelitian Kesehatan. Jakarta: EGC

Padila. 2013. Asuhan Keperawatan Penyakit Dalam. Yogyakarta: Nuha Medika

Probowo. 2014. Konsep Dan Aplikasi Asuhan Keperawatan Jiwa. Yogyakarta: Nuha Medika

Prasetya, A. 2014. Pengaruh Pendidikan Kesehatan Terhadap Tingkat Ansietas. Jurnal Kesehatan Metro Sai Wawai. Vol. VII No I Edisi Juni 2014. ISSN 19779-466

Price, A \& Wilson, M. 2008 Patofisiologi Konsep Klinis Proses-Proses Penyakit . Jakarta : EGC

Profil Kesehatan Provinsi Jambi Tahun 2017

Riyadi \& Purwanto, T. 2009. Asuhan Keperawatan Jiwa. Yogyakarta: Graha IImu

Rizkiya (2017) dengan judul pengaruh teknik 5 jari terhadap tingkat ansietas klien gangguan fisik yang dirawat di RSU Kendal. Jurnal Keperawatan Muhammadiyah. 
Setiawan. 2014. Strategi Pelaksanaan Ansietas. https://www.wordpress.com/. Diakses tanggal 7 Mei 2018

Sulistyarini, I. 2013. Terapi Relaksasi Untuk Menurunkan Tekanan Darah Dan Meningkatkan Kualitas Hidup Penderita Hipertensi. Jurnal Psikologi. Vol. 40. 2838

Sujono, R \& Teguh, P. 2013. Asuhan Keperawatan Jiwa. Yogyakarta: Nuha Medika

Stuart, G.W. 2012. Buku Saku Keperawatan Jiwa. Jakarta: EGC

Stuart, G.W. 2012. Buku Saku Keperawatan Jiwa. Jakarta: EGC

Waluyo. 2013. Terapi Musik. Yogyakarta: Nuha Medika

World Health Organization (WHO). 2014. Commission On Ending Childhood Obesity. Geneva, World Health Organization, Departement Of Noncommunicable Disease Surveillance 